Chirurgia (2017) 112: 607-610

No. 5, September - October

Copyright $\odot$ Celsius

http://dx.doi.org/10.21614/chirurgia.112.5.607

\title{
Apps in Trauma and Emergency Surgery
}

\author{
Ahmed Saad', Saira Bibi', Parveen Vitish-Sharma', Yan Mei Goh', Peep Talving'르, Luca Ponchietti' \\ ${ }^{1}$ Department of General Surgery, Milton Keynes University Hospital, Eaglestone, Milton Keynes, United Kingdom \\ ${ }^{2}$ Institute of Clinical Medicine, Department of Surgery, University of Tartu, Tartu, Estonia
}

Corresponding author:

Ahmed Saad, PhD, MSc, MRCS(Eng), MBBS

Department of General Surgery, Milton Keynes University Hospital, Standing Way, Eaglestone, Milton Keynes, MK6 $5 \mathrm{LD}$, United Kingdom.

E-mail: ahmed.saad@mkuh.nhs.uk
Received: 26.07.2017 Accepted: 15.08 .2017

\section{Rezumat}

\section{Aplicatiii în chirurgia traumatică și de urgență}

Date generale: Telefoanele mobile de tip smartphone, laptopurile şi tabletele fac în prezent parte integrală din activitățile noastre de zi cu zi în calitate de clinicieni, atât pentru comunicarea de natură personală, cât şi ca parte din practica clinică de rutină.

Metodă: Un sondaj digital a fost creat pentru a explora gradul de utilizare al telefoanelor de tip smartphone si al aplicatiilor asociate în rândul chirurgilor din sectiile de chirurgie de urgență şi traumă. Acesta a fost trimis către 850 de membri ai Societății Europene de Chirurgie de Urgență şi Traumă.

Rezultate: 91 de persoane au răspuns la sondajul nostru, 60,4\% dintre acestea fiind de vârste cuprinse între 35 şi 54 de ani. Doar $24,1 \%$ dintre cei care au răspuns consideră aplicațiile disponibile foarte utile în activitatea lor, în timp ce $75,9 \%$ dintre cei care au participat au căzut de acord asupra lipsei posibilității de a identifica o anume aplicație de calitate pe care să se bazeze.

Concluzii: În ciuda utilizării la scară largă a telefoanelor tip smartphone în rândul doctorilor de diferite grade şi specialități, există o preferință către utilizarea aplicațiilor de tip mesaj instant şi a camerei foto pentru efectuarea fotografiilor clinice. Utilitatea aplicațiilor disponibile actualmente pare a fi limitată de absența unui organ de reglementare care să verifice validitatea datelor şi a posibilității de evaluare reciprocă a conținutului aplicațiilor, lăsând o responsabilitate enormă să cadă pe umerii fiecărui medic utilizator care se încrede în rezultatele aplicației. 
Cuvinte cheie: chirurgie de urgență, telefoane smartphones, aplicații medicale

\begin{abstract}
Background: As physicians, Mobile smartphones, laptops and tablets are now an integral part of our day to day activities including personal communications as well as our routine clinical practice.

Methods: A digital survey was designed to explore the usage of mobile smartphones and the associated apps among surgeons in Trauma and Emergency departments. It was sent to 850 members of the European Society for Trauma and Emergency Surgery.

Results: A total of 91 responses were received with $60.4 \%$ aged between 35 and 54 years. Only $24.1 \%$ of respondents found the available apps extremely useful in their practice, however $75.9 \%$ of participants agreed on not being able to identify a certain good application to rely on.

Conclusion: Despite the widespread use of smartphones among doctors of different grades and specialties, there is a preference shown towards the use of instant messenger apps and the use of the camera for clinical photos. The usefulness of current available apps appears to be limited due to the absence of a regulating body to check the validity of data and peer review the contents of apps leaving a huge responsibility on the individual doctor using the app to rely on its results.
\end{abstract}

Key words: emergency surgery, smartphones, medical apps

\section{Introduction}

Technology has invaded every aspect of our lives including medical practice. As physicians, Mobile smartphones, laptops and tablets are now an integral part of our day to day activities including personal communications as well as our routine clinical practice. They are rapidly replacing the conventional desktop computers.

Access to medical websites for up-to-date evidence, exchange of clinical expertisevia advice among social media groups, as well as the use of clinical apps as medical calculators and scoring systems are among the many capabilities available to smartphones users. Thousands of medical applications are now available in the market. At present, more than 500000 medical apps are available on the Apple app store (1).

Several surveys and studies have been designed to look into the use of smartphones and mobile apps among different specialities. Franko and Tirrell (2) found that $56 \%$ of physicians among 27 medical specialities are using medical apps in their practice. Payne et al1 concluded that $79 \%$ of medical students and $74.8 \%$ of junior doctors in the UK used medical apps on their smartphones.

Despite the widespread use of medical apps among doctors of different grades and specialties, no clear preference was mentioned in any of the published data. Furthermore, there have been many concerns raised across the medical practice regarding confidentiality and the risk of loss of patient related information even though the attempts for encryption in many of those apps. Absence of a regulating body to check the validity of data and peer review the contents of those apps is still a major limitation at the time being leaving a huge responsibility on the individual doctor using the app to rely on its results.

\section{Methods}

A digital survey was conducted to explore the usage of mobile smartphones and the associated apps among surgeons in Trauma and Emergency departments. The questionnaire was designed on SurveyMonkey to collectdemographic data regarding age and grade of participants and the use of smart- 
phones in their medical practice were collected. Focus was placed on the use of medical and non-medical apps and the types and frequency of their use. Focus was placed on apps used to include: simple medical calculators; scoring systems; institutional apps; and guidelines. Participants were also questioned on their use of core smartphone functions such as: web browsing for literature search; use of built-in camera; or day to day social apps including Messenger and WhatsApp. Respondents' opinion regarding which apps were used; or whether they had any preferences on choice of app was also surveyed.

The survey was sent in April 2007 to all members of the European Society for Trauma and Emergency Course $(n=850)$. The collected data was analysed using SPSS statistics as well as Microsoft Excel programmes.

\section{Results}

Ninety-one responses were received over a one month period. All respondents were aged between 25 to 75 . Of the 91 participants, $60.4 \%$ were aged between 35 and 54 years, and $23.33 \%$ were between 55 and 64 years old. No medical students participated in this survey. Around $63 \%(\mathrm{n}=57)$ were consultant surgeons. Twentyone participants $(23.33 \%)$ were surgical trainees or middle grade doctors, with $65.9 \%$ using the iOS system.

Of the participants, $73.6 \% \quad(n=67)$ had medical apps on their devices. About $60 \%$ of respondents never or seldom used the institutional apps. Slightly more than 50.0\% never or seldom used scoring system apps. However more than $80.0 \%$ relied on the non-medical social apps such as Messenger or WhatsApp as well as using their built-in camera for taking photos or videos for clinical documentation and sought of expertise and advice.

Only $24.1 \%(n=22)$ of respondents found the available apps extremely useful in their practice in trauma and emergency surgery however $75.9 \%(n=65)$ of participants agreed on not being able to identify a certain good application to rely on.

Interestingly, when asked how much would they pay for a good App, 64.8\% $(n=59)$ were keen to pay 10 Euros at most, $24.2 \%(n=22)$ would have paid between 11 and 50 Euros and only $11.0 \%(n=10)$ would pay more than 50 Euros.

\section{Discussion}

The majority of our respondents were between 35-64 years of age. Only 2 participants were above 65 years old which is likely to reflect the reduced interest in the use of technology in more senior population of surgeons. Most of the respondents believe that it is difficult to find good Apps and most of them used their smartphones to access non-medical and social apps (WhatsApp, built in camera and literature review Apps). Medical calculator, scoring systems (P-possum /SOFA), and institutional apps are never used by $75 \%$ of the respondents

A large number of our respondents (73.6\%) had medical apps on their smartphone. Of these $59.8 \%$ used institutional apps, compared to $88.6 \%$ who used instant messenger apps (Whatsapp, imessages) and 87.8\% used smartphones to carryout literature searches. Interestingly, $65 \%$ would only pay up to 10 Euros compared to $11.0 \%$ suggested they would pay more than 50 Euros for a decent application. The reluctance to financially commit to medical apps is likely to be indicative of how their utility is perceived among the cohort of doctors who participated to the Survey.

Our results are in line with published articles. Orrin et al looked at the use of smartphone apps in medicine in 2011. They found greater than $85 \%$ used smartphones in 2011, all of our respondents had access to a smartphone. In their study, they found $56 \%$ used apps in clinical practice; we found $68.9 \%$ used medical apps. They found $56 \%$ used iOS systems compared to $65.9 \%$ in our study (2). O'Connor et al carried out a survey involving 108 interns. They found $94.4 \%$ owned a smartphone, $52.9 \%$ used their phone to take clinical photos, compared to $93.3 \%$ in our study (3).

There are limitations to our study include the modest sample size and the small number of participants across multiple countries. 


\section{Conclusion}

Despite the widespread use of smartphones among doctors of different grades and specialties, there is a preference shown towards the use of instant messenger apps and the use of the camera for clinical photos. The usefulness of current available apps appears to be limited according to the views of our respondents. This could be due to the absence of a regulating body to check the validity of data and peer review the contents of those apps is still a major limitation at the time being leaving a huge responsibility on the individual doctor using the app to rely on its results.
Financial support: None.

Conflicts of interest: None.

\section{References}

1. Payne KB, Wharrad H, Watts K. Smartphone and medical related App use among medical students and junior doctors in the United Kingdom (UK): a regional survey. BMC Med Inform Decis Mak. 2012;12:121. doi: 10.1186/1472-6947-12-121.

2. Franko OI, Tirrell TF. Smartphone app use among medical providers in ACGME training programs. J Med Syst. 2012;36(5):3135-9. doi: 10.1007/s10916-011-9798-7. Epub 2011 Nov 4.

3. O'Connor P, Byrne D, Butt M, Offiah G, Lydon S, Mc Inerney K, et al. Interns and their smartphones:use for clinical practice. Postgrad Med J. 2014;90(1060):75-9. doi: 10.1136/postgradmedj-2013131930. Epub 2013 Nov 15. 